を酶酸エチルで分解し，水を加えて不溶の水酸化アルミニウムを 口別する。口液からテトラヒドロフランを留去し含水エタノール で再結晶する。 $\mathrm{mp} 169 \sim 174^{\circ} \mathrm{C}_{0}$ IR, 薄層クロマトグラフィー で 3.10.1 でえたものと同定した。

3.11 サングイソルビゲニンジオール[5]

3.11 サングイソルビゲニンジオール-3-アラビノシドの酸 加水 分解: サングイソルビゲニンジオール-3-アラビノシド [ 3$]$ $214 \mathrm{mg}$ をメタノール $15 \mathrm{ml}$ に溶かし, 濃塩酸 $2 \mathrm{ml}$ を加えて 5 時間還流する。メタノールの一部を留去し, 水を加えて生じる 結晶 $146 \mathrm{mg}$ をロ別し，メタノールから再結晶する。 $\mathrm{mp} \mathrm{185〜}$ $189^{\circ} \mathrm{C}$, 針状結晶。

分析值 G $78.31 \%, \mathrm{H}$ 10.96\%
$\mathrm{C}_{30} \mathrm{H}_{48} \cdot \mathrm{O}_{2} \cdot \mathrm{H}_{2} \mathrm{O}$ としての計算值 $\mathrm{C} 78.55 \%, \mathrm{H} \quad 10.99 \%$ 口液を濃縮し，Amberlite IRA-410 で酸を除き，1-ブタノ一 ルー酢酸-水 $(4: 1: 2)$ でペーパークロマトグラフィーにかけると アラビノースが検出された。

3.11 .2 サングインルビゲニンメチルエステルの還元: サング イソルビゲニンメチルエステル $7.6 \mathrm{~g}$ をーテル $200 \mathrm{ml}$ に溶 かし，水素化アルミニウムリチウム $4.0 \mathrm{~g}$ のエーテル $300 \mathrm{ml}$ の溶液に加え，4.5 時間還流する。酢酸エチルで過剩の還元剤を 分解し， $10 \%$ 硫酸で酸性にし，エーテル層をとる。エーテルを 留去し, 残留物をメタノールから再結晶する。 $\mathrm{mp} 185 \sim 189^{\circ} \mathrm{C}_{\circ}$ IR，薄層クロマトグラフィーで 3.11 .1 でえたものと同定した。

\title{
アルキルロジウム錯 体の合成
}

(昭和 43 年 7 月 1 日受理)

武貞 正 彦*1 $\cdot 山$ 崎 博 史*2. 萩 原 信 衞*2

(1,5-シクロオクタジェン)(トリフェニルホスフィン)ロジウムクロリド $\mathrm{Rh}(1,5-\mathrm{COD})\left(\mathrm{Ph}_{3} \mathrm{P}\right) \mathrm{Gl}$ と $\mathrm{Grignard}$ 試薬との反応に より $\mathrm{RRh}(1,5-\mathrm{COD})\left(\mathrm{Ph}_{3} \mathrm{P}\right)$ 型のロジウム( I )のアルキル錯体 $\left(\mathrm{R}=\mathrm{CH}_{3}, \mathrm{C}_{6} \mathrm{H}_{5} \mathrm{CH}_{2}, \mathrm{C}_{6} \mathrm{H}_{5}\right)$ を合成した。同じ型のエチルおよび イソプロピル錯体はえられなかったが，過剩のトリフェニルホスフィンの存在下に $\mathrm{Rh}(1,5-\mathrm{COD})\left(\mathrm{Ph}_{3} \mathrm{P}\right) \mathrm{Gl}$ と臭化エチルマグネ シウムとを反応させるとエチレンの生成をともなって $\mathrm{HRh}\left(\mathrm{Ph}_{3} \mathrm{P}\right)_{4}$ がえられた。アルキル錯体の核磁気共鳴スペクトルで，配位 した 1,5-シクロオクタジェンのオレフィン性水素が大きく分裂した 2 本の吸収を示した。これに関連し，数種の Rh(1,5-GOD) LX 型の錯体を合成し，それらのオレフィン性水素の吸収について考察した。

\section{1 緒言}

遷移金属のアルキル錯体は，遥移金属錯体を触媒とする均一系 反応の中間体と考えられる場合が多いため興味がもたれている。 著者らの研究空においても, 触煤反応の機構と関連して, ニッケ ルおよびコバルトのアルキル錯体についての研究を進めてきた1) が, さらにロジゥムのアルキル錯体について拡張するため本研究 を始めた。

形式的原子価が 3 価のロジウムのアルキル錯体は， ロジウム （III）八ロゲン化物と Grignard 試薬との反応2)，ロジウム（Ｉ）錯 体へのハロゲン化アルキルなどの酸化的付加反応3)，およびロジ

*1 Masahiko TAKESADA 現在 味の素株式会社中央研究所, 川崎市鈴木町

*2 Hiroshi YAMAZaKI, Nobue Hagrhara 大阪大学産業科 学研究所, 堺市東浅香山町

1) H. Yamazaki, N. Hagihara, Bull. Chem. Soc. Japan, 37, 908(1964); 38, 2212(1965); J. Organometal. Chem., $6,86(1966) ; 7,22(1967)$.

2) a J. Chatt, A. E. Underhill, J. Chem. Soc., 1963, 2088.

b) H. P. Fritz, K. Schwarzhans, J. Organometal. Chem., 5, 283(1966).

c) A. Kasahara, T. Izumi, K. Tanaka, Bull. Chem. Soc. Japan, 40, 699(1967).

3) a) F. Heck, J. Am. Chem. Soc., 86, 2796(1964).

b) J. Altman, G. Wilkinson, J. Chem. Soc., 1964, 5654.

c) D. N. Lawson, J. A. Osborn, G. Wilkinson, J. Chem. Soc. $(A), 1966,1733$.
ウム (III) ヒドリド錯体へのオレフィンの挿入反応4などによって 数種のものの合成が報告されている。しかし形式的原子価が 1 価 のロジウムのアルキル錯体は，安定な錯体として単離されていな かった。最近になって Keim が $R R h\left(\mathrm{Ph}_{3} \mathrm{P}\right)_{3}$ 型の錯体の合成に ついて簡単に報告しているにすぎない5)。

一般に，低原子価の遷移金属アルキル錯体は不安定であり，そ

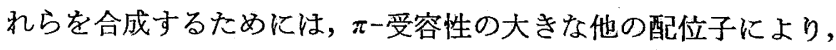
金属-炭素 $\sigma$ 結合を安定化させることが必要である場合が多いこ とが知られている6)。著者らは，パラジウム (II), 白金(II)のア ルキル錯体を安定化することが知られている配位子，第三級ホス フィン7および 1,5-シクロオクタジェン8)(以下 1,5-COD と記 す)をともに配位したロジウム（I）アルキル錯体の 合成を試み， $\mathrm{RRh}(1,5-\mathrm{COD})\left(\mathrm{Ph}_{3} \mathrm{P}\right)$ 型の錯体をえることができた。

本報では，この錯体の合成について検討を行なった結果，明ら

4) a) K. C. Dewhirst, Inorg. Chem., 5, 319(1966).

b) M. G. Baird, J. T. Magve, J. A. Osborn, G. Wilkinson, J. Chem. Soc. (A), 1967, 1347.

c) J. A. Osborn, A. R. Powell, G. Wilkinson, Chem., Commun., 1966, 461.

5) W. Keim, J. Organometal. Chem., 8, P 25(1967).

6) 萩原信衞, “有機金属の化学と応用”, 朝倉書店 (1962) p. 239.

7) G. Galvin, G. E. Coats, Chem. Ind. (London), 1958, 160; J. Ghatt, B. L. Shaw, J. Chem. Soc., 1959, 705.

8) G. Calvin, G. E. Coats, J. Chem. Soc., 1960, 2008; C. R. Kistner, J. H. Hutchinson, J. R. Doyle, J. G. Storlie, Inorg. Chem., 2, 1255(1963); J. Müller, P. Göster, Angew. Chem., 79, 308(1967). 
表 1 フルキルロジウム錯体 $\mathrm{RRh}(1,5-\mathrm{COD})\left(\mathrm{Ph}_{3} \mathrm{P}\right)$

\begin{tabular}{|c|c|c|c|c|c|c|c|c|c|}
\hline \multirow{3}{*}{$\mathbf{R}$} & \multirow{3}{*}{$\begin{array}{l}\text { 収率 } \\
(\%)\end{array}$} & \multirow{3}{*}{$\begin{array}{c}\text { 融点 (分解) } \\
\left({ }^{\circ} \mathrm{C}\right)\end{array}$} & & & \multicolumn{5}{|c|}{$\operatorname{NMR}$ スペクトルc) $(\tau)$} \\
\hline & & & \multicolumn{2}{|c|}{ 元素分析値 (\%) } & \multirow{2}{*}{$\begin{array}{l}フ ェ= \\
\text { ル基の } \\
\text { 水素 }{ }^{d)}\end{array}$} & \multicolumn{2}{|c|}{ 1,5-COD の } & \multirow{2}{*}{$\begin{array}{l}\text { メチレ } \\
\text { ソ基の. } \\
\text { 水素 }\end{array}$} & \multirow{2}{*}{$\begin{array}{l}\text { メチル } \\
\text { 基の水 } \\
\text { 素 }\end{array}$} \\
\hline & & & $\mathrm{G}$ & $\vec{H}$ & & オレフィン性水絜り & メチレ水素e) & & \\
\hline $\mathrm{C}_{6} \mathrm{H}_{5}$ & 65 & $134 \sim 137$ & $\begin{array}{l}69.38 \\
(69.82)^{b)}\end{array}$ & $\begin{array}{c}5.97 \\
(5.86)\end{array}$ & $2.3 \sim 3.2$ & $\begin{array}{l}4.96 \\
6.04\end{array}$ & 7.85 & & \\
\hline $\mathrm{C}_{6} \mathrm{H}_{5} \mathrm{CH}_{2}$ & 29 & $119 \sim 120$ & $\begin{array}{c}69.92 \\
(70.21)\end{array}$ & $\begin{array}{c}6.09 \\
(6.07)\end{array}$ & $1.9 \sim 3.3$ & $\begin{array}{l}5.38 \\
6.28\end{array}$ & 8.04 & $7.62^{f)}$ & \\
\hline $\mathrm{CH}_{3}$ & 52 & $74 \sim 76$ & & & $2.0 \sim 3.2$ & $\begin{array}{l}4.85 \\
6.28\end{array}$ & 7.92 & & $9.64 g)$ \\
\hline
\end{tabular}

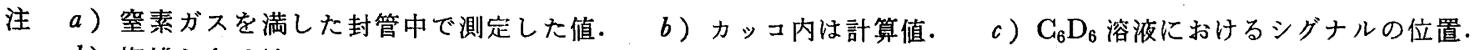

$d$ ）複雑な多重線の吸収を示す。 $e$ ) 分離しない幅広い吸収であり，面積中心位置を示す.

$f$ ) 間隔が $2.0 \mathrm{cps}$ の二重線. $g$ ) 間隔が $1.1 \mathrm{cps}$ の二重線.

かにされた若干の知見について報告する。

\section{2 実験結果および考察}

\section{1 アルキルロジゥム錯体の合成}

$[\mathrm{Rh}(1,5-\mathrm{COD}) \mathrm{Gl}]_{2}$ と当量のトリフェニルホスフィンを含む ベンゼン溶液を氷冷下に Grignard 試薬で処理して, 橙色結晶と して,フェニル, ベンジルおよびメチルロジウム錯体をえた。

$$
\begin{gathered}
\frac{1}{2}\left[\mathrm{Rh}(1,5-\mathrm{COD}) \mathrm{Cl}_{2}+\mathrm{Ph}_{3} \mathrm{P}+\mathrm{RMgX}\right. \\
\longrightarrow \mathrm{RRh}(1,5-\mathrm{COD})\left(\mathrm{Ph}_{3} \mathrm{P}\right) \\
\mathrm{R}=\mathrm{C}_{6} \mathrm{H}_{5}, \mathrm{C}_{6} \mathrm{H}_{5} \mathrm{CH}_{2}, \mathrm{CH}_{3}
\end{gathered}
$$

合成した錯体の IR スペクトルは, $\mathrm{Rh}(1,5-\mathrm{COD})\left(\mathrm{Ph}_{3} \mathrm{P}\right) \mathrm{Gl}$ の それと類似しており, 配位したトリフェニルホスフィンによる特 徵ある吸収を示した。'収率, 融点, 元素分析值および NMR スペ クトルの結果を表 1 に示す。

フェニルおよびベンジル錯体の元素分析值, NMR スペクトル および IR スペクトルは, これらの鍇体が RRh(1,5-GOD) $\left(\mathrm{Ph}_{3} \mathrm{P}\right)$ の組成のものであることを支持している。メチル錯体はきわめて 不安定であるため元素分析値はえられなかったが， $\mathrm{C}_{6} \mathrm{D}_{6}$ 中での NMR スペクトルは，ロジウムに結合したメチル基に帰属される $9.64 \tau$ の吸収を示した。 $\left(\mathrm{CH}_{3}\right)_{2} \mathrm{Rh}\left(\pi-\mathrm{C}_{5} \mathrm{H}_{5}\right)\left(\mathrm{Ph}_{3} \mathrm{P}\right)^{2 \mathrm{c})}, \mathrm{CH}_{3} \mathrm{Rh}$ $\left.\left.\left.\mathrm{ClI}\left(\mathrm{Ph}_{3} \mathrm{P}\right)_{2}\left(\mathrm{ICH}_{3}\right)^{3 \mathrm{c}}\right), \mathrm{CH}_{8} \mathrm{RhCl}_{2}(\mathrm{CO})^{4 \mathrm{~b}}\right), \mathrm{CH}_{8} \mathrm{Rh}\left(\mathrm{Ph}_{3} \mathrm{P}\right)_{3}{ }^{5}\right)$ の NMR スペクトルから考えると，このメチル基の水素の吸収は， ${ }^{103} \mathrm{Rh}$ および ${ }^{31} \mathrm{P}$ とのカップリングにより， 2 組の二重線を示す

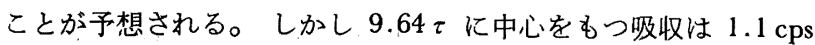
の間隔をむつ二重線を示すのみで，この錯体ではメチル基の水素 と ${ }^{103} \mathrm{Rh}$ または ${ }^{31} \mathrm{P}$ とのカップリングのうちいずれか一方が小 さく検出されなかったものと考えられる。同様のことがベンジル 錯体でもみられ，ベンジル基のメチレン水素に帰属される $7.62 \tau$ の吸収は, $2.0 \mathrm{cps}$ の間隔をもつ二重線を示すのみであった。ま たメチル錯体の $\mathrm{CH}: \mathrm{CH}_{2}: \mathrm{CH}_{3}$ 水素の吸収の面積比がほぼ $4: 8: 3$ であることから，メチル錯体もフェニルおよびベンジル 錯体と同しように, $\mathrm{CH}_{3} \mathrm{Rh}(1,5-\mathrm{COD})\left(\mathrm{Ph}_{3} \mathrm{P}\right)$ なる組成のもので あるととがわかる。

これらのアルキル錯体は，その分解点からもわかるように，熱 的にはかなり安定であり, 窒素雾围気中では室温でも長期間保存 することができたが，酸素に对してはいずれもきわめて不安定で あり，溶液状態ではもちろんのこと，メチル錯体では固体状態で も空気に接触するとただちに変化した。これらの錯体の酸素に対
する安定性は, フェニル>ベンジル>メチル錯体の順に减少し, 窒素中での分解点で示される熱安定性の順序と一致している。

メチル錯体を合成する反応で，遊離の臭化メチルあるいはヨウ 化メチルのない Grignard 試薬を用いるとメチル錯体をえること ができたが，過剩のヨウ化メチルを含むGrignard 試薬を用いる とメチル錯体はえられず， $\mathrm{Rh}(1,5-\mathrm{COD})\left(\mathrm{Ph}_{3} \mathrm{P}\right) \mathrm{I}$ が生成した。 四配位のロジウム ( I )の錯体がハロゲン化アルキルと酸化的付加 反応をすることが知られており3)，またフェニル錯体が室温でョ ウ化メチルあるいはヨウ化エチルと反応し $\mathrm{Rh}(1,5-\mathrm{COD})\left(\mathrm{Ph}_{3} \mathrm{P}\right)$ I を生成することから，いったん生成したメチル錯体が系中に存 在するョウ化メチルと反応し $\mathrm{Rh}(1,5-\mathrm{COD})\left(\mathrm{Ph}_{3} \mathrm{P}\right) \mathrm{I}$ を生成し たと考えられる。この結果は，式(1)に示した方法でアルキル錯 体を合成するには, 活性なハロゲン化アルキルが存在しない系で 行なわねばならないことを示している。

式（1）に示した方法を用いてエチルおよびィソプロピル錯体の 合成を試みたが成功しなかった。 $[\mathrm{Rh}(1,5-\mathrm{COD}) \mathrm{Cl}]_{2}$ と当量の トリフェニルホスフィンを含むベンゼン溶液と臭化エチルマグネ シウムとの反応中には少量のエタンとともにエチレンが生成し， また $[\mathrm{Rh}(1,5-\mathrm{COD}) \mathrm{Cl}]_{2}$ に対し 4 倍当量のトリフェニルホスフ ィン存在下での臭化エチルマグネシウムとの反応では, エチレン の発生をともなってヒドリド錯体 $\mathrm{HRh}\left(\mathrm{Ph}_{3} \mathrm{P}\right)_{4}{ }^{9}{ }^{9}$ が生成した。こ れらの事実から，エチル錯体がえられなかったのは，式(2)に示 すように中間に生成したエチルロジウム錯体が，承冷下の条件で もすみやかにエチレンとヒドリド錯体へと変化していくためと推 定される。エチル錯体の同じょうな挙動は白金（II )錯体でもみら

$$
\begin{aligned}
\frac{1}{2} & {\left[\mathrm{Rh}(1,5-\mathrm{COD}) \mathrm{Cl}_{2}+\mathrm{Ph}_{3} \mathrm{P}+\mathrm{C}_{2} \mathrm{H}_{5} \mathrm{MgBr}\right.} \\
& \longrightarrow\left[\mathrm{C}_{2} \mathrm{H}_{5} \mathrm{Rh}(1,5-\mathrm{COD})\left(\mathrm{Ph}_{3} \mathrm{P}\right)\right] \\
& \longrightarrow \mathrm{CH}_{2}=\mathrm{CH}_{2}+\mathrm{HRh}(1,5-\mathrm{COD})\left(\mathrm{Ph}_{3} \mathrm{P}\right)
\end{aligned}
$$

れ，安定なエチル錯体 trans- $\left[\mathrm{PtClC}_{2} \mathrm{H}_{5}\left(\mathrm{Et}_{3} \mathrm{P}\right)_{2}\right]$ を $180^{\circ} \mathrm{G}$ に加熱 すると trans- $\left[\mathrm{PtClH}\left(\mathrm{Et}_{3} \mathrm{P}\right)_{2}\right]$ が生成することが知られている10)。 この場合エチル基の $\beta$-位にある水素が白金に移動しェチレンが 生成したと考えられている。エチル錯体の場合と同じように，イ ソプロピル錯体合成の試みのさいにも過剩のトリフェニルホスフ ィン存在下では $\mathrm{HRh}\left(\mathrm{Ph}_{3} \mathrm{P}\right)_{4}$ が生成した。これらの結果は, 口 ジウム (I)の錯体では, 低温でもアルキル基上の $\beta$-位の水素の

9) M. Takesada, H. Yamazaki, N. Hagihara, Bull. Chem. Soc. Japan, 41, 270(1968).

10) J. Chatt, B. L. Shaw, J. Chem. Soc., 1962, 5075. 
移動が容易に起こることを示しており，炭秦数 2 以上のアルキル 基をもつロジウム (I ) 錯体を合成するためには，よりいっそう温 和な条件下での処理が必要と考えられる。

アリルロジウム錯体を合成するため，臭化アリルマグネシウム を用いて式 (1)の反応を行ない淡橙色の結晶をえた。このものの NMR スペクトルは配位した 1,5-COD による吸収を示さず，元 素分析, NMR スペクトルの結果から, 最近 Reillyら ${ }^{11)}$ にっ て合成された $\left(\pi-\mathrm{C}_{3} \mathrm{H}_{5}\right) \mathrm{Rh}\left(\mathrm{Ph}_{3} \mathrm{P}\right)_{2}$ と同一の錯体である

$\frac{1}{2}[\mathrm{Rh}(1,5-\mathrm{COD}) \mathrm{Cl}]_{2}+\mathrm{Ph}_{3} \mathrm{P}+\mathrm{CH}_{2}=\mathrm{CHCH}_{2} \mathrm{MgBr}$

$$
\longrightarrow \mathrm{HC}_{\mathrm{CH}_{2}}^{\mathrm{CH}_{2}} \mathrm{Rh}\left(\mathrm{Ph}_{3} \mathrm{P}\right)_{2}
$$

\section{ことがわかった。}

\subsection{1,5-シクロオクタジエンロジゥム錯体の NMR スペクト} ル

1,5-COD が配位した遷移金属錯体の NMR スペクトルでその オレフィン性水素は 1 本の吸収を示すととが知られている12)。し かし著者らの合成したアルキルロジウム錯体 RRh(1,5-COD) $\left(\mathrm{Ph}_{3} \mathrm{P}\right)$ の NMR スペクトルでは, 1,5-COD のオレフィン性水素 がそれぞれ面積の等しい 2 本の吸収に大きく分裂した(表 1$)$ 。こ の分裂について検討するため， $\mathrm{Rh}(1,5-\mathrm{COD}) \mathrm{LX}$ 型の種々の錯 体を合成し，その NMR スペクトルを測定した。オレフィン性水 素の吸収位置を図 1 に示す*3。

この分裂は，その大きさからオレフィン性水素と ${ }^{1} \mathrm{H},{ }^{103} \mathrm{Rh}$ あ るいは ${ }^{31} \mathrm{P}$ とのカップリングによるものとは考光難い。このこと は $[\mathrm{Rh}(1,5-\mathrm{COD}) \mathrm{Gl}]_{2}, \mathrm{Rh}(1,5-\mathrm{COD})\left(\mathrm{NH}_{3}\right) \mathrm{Cl}$ などでは分裂 がみられないこと，また $\mathrm{Rh}(1,5-\mathrm{COD})\left(\mathrm{Ph}_{3} \mathrm{As}\right) \mathrm{Cl}$ でも分裂がみ られることからも明らかである。配位したシクロオクタジェンが 1,5-ジェン構造のままであることは, $\mathrm{C}_{6} \mathrm{H}_{5} \mathrm{Rh}$ (1,5-COD) $\left(\mathrm{Ph}_{3} \mathrm{P}\right)$ をトリフェニルホスフィン存在下に酸素と反応させ生成する $\mathrm{Rh}$ $\left(\mathrm{Ph}_{3} \mathrm{P}\right)_{3} \mathrm{O}_{2}$ 9) を除いたロ液中に 1,5-COD が .97\% の収率で生成 しているとと, および $\mathrm{Rh}(1,5-\mathrm{COD})\left(\mathrm{Ph}_{3} \mathrm{P}\right) \mathrm{Cl}$ をシアン化ナト リウムで処理すると 1,5-COD のみを生成することから明らかで ある。またこれらの錯体が溶液中で解離していなことは， Rh(1， 5-COD) $\left(\mathrm{Ph}_{3} \mathrm{P}\right) \mathrm{Cl}, \mathrm{Rh}(1,5-\mathrm{COD})\left(\mathrm{Et}_{3} \mathrm{P}\right) \mathrm{Cl}$, および $\mathrm{Rh}(1,5-$ COD) $\left(\mathrm{C}_{5} \mathrm{H}_{5} \mathrm{~N}\right) \mathrm{Cl}$ の溶液中での分子量測定の結果が解離してい ない単量体の計算值に一致することから明らかであり，また解離 しているならそれをおさえることを予期し， Rh(1,5-COD) $\left(\mathrm{Ph}_{3}\right.$ P) Cl K 1,5-COD(〜 5 倍モル)あるいはトリフェニルホスフィン (〜 1 倍モル)を，また $\mathrm{Rh}(1,5-\mathrm{COD})\left(\mathrm{C}_{5} \mathrm{H}_{5} \mathrm{~N}\right) \mathrm{Gl}$ に 1,5-GOD

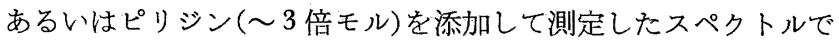
も，配位した 1,5-GODによる吸収の位置にほとえど変化が認め られなかったことからもわかる。

これらの事実は平面 4 配位の $\mathrm{Rh}(1,5-\mathrm{COD}) \mathrm{LX}$ の構造のまま

11) G. A. Reilly, H. Thyret, J. Am. Chem. Soc., 89, 5144 (1967).

12) J. Müller, E. O. Fischer, J. Organometal. Chem., 5, 277 (1966).

*3 著者らの研究が終了したのち, $\mathrm{Rh}(1,5-\mathrm{COD})\left(\mathrm{Ph}_{3} \mathrm{P}\right) \mathrm{Cl}$, $\mathrm{Rh}(1,5-\mathrm{COD})\left(\mathrm{As}_{3} \mathrm{P}\right) \mathrm{Cl}$ の $\mathrm{NMR}$ スペクトルにおいて, オレフィン性水素が 2 本の吸収に分裂することが速報さ れた. K. Vrieze, H. G. Volger, J. Organometal. Chem., 11, P 17(1968). $\tau$ 值

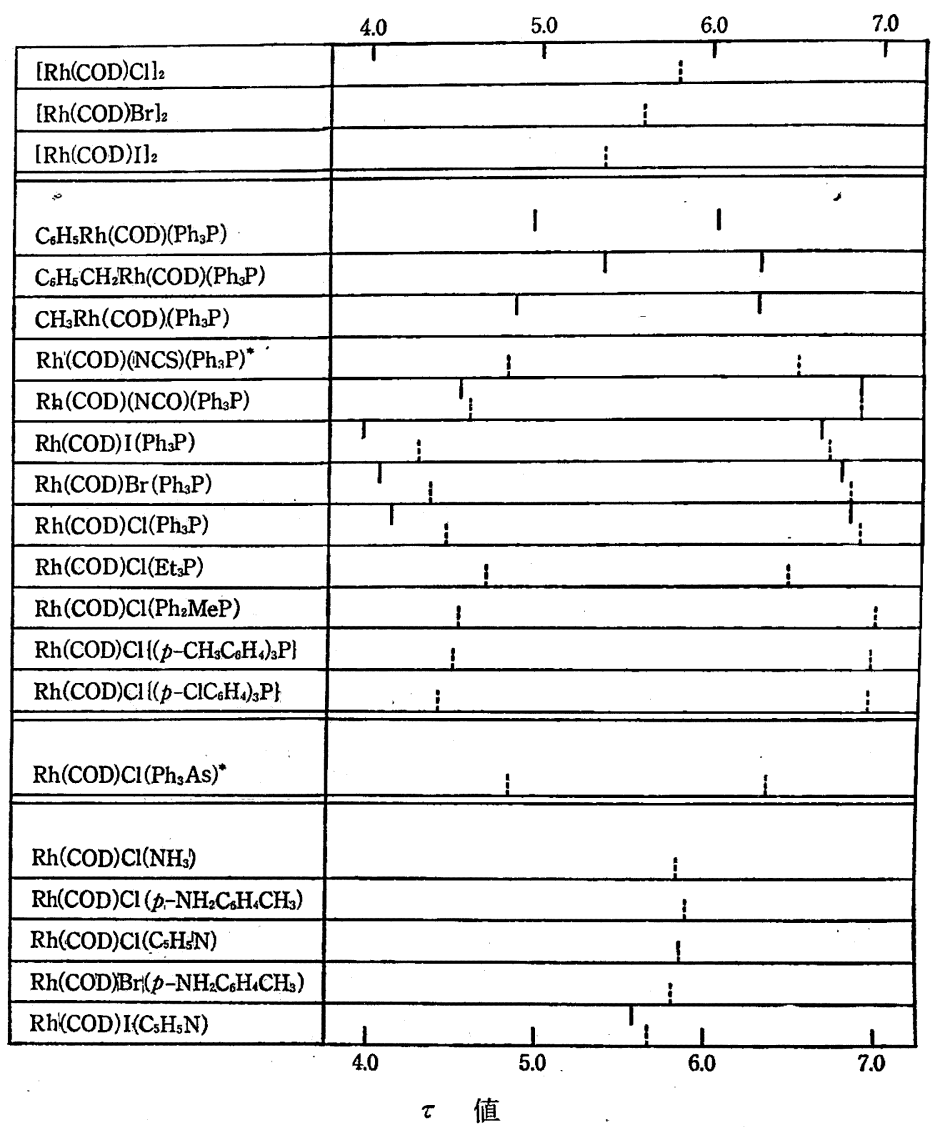

- 溶媒 $\mathrm{C}_{6} \mathrm{D}_{6}, \quad-\cdots$ : 溶媒 $\mathrm{CDCl}_{3}$

COD: 1,5-シクロオクタジェン

*:オレフィン性水素の吸収がきわめて幅広かった。

図 1 1, 5-シクロオクタジェンロジウム錯体の NMR スペクトル (オレフィン性水素の吸収位置)

で，1,5-COD のオレフィン性水素に磁気的に非等価な水素が存 在することを示していると考えられる。 Rh(1,5-COD)LX 型の 錯体でLがアミン類の場合には 1 本, $\mathrm{PR}_{3}$ あるいは $\mathrm{AsR}_{3}$ の場合 には 2 本の吸収を示す。アミン類がほとんど $\pi$ 受容性をもたず， ホスフィンなどが大きな $\pi$ 一受容性をもっていることから考える と，この分裂は配位子の $\pi$-受容性に起因していることが推定さ れる。すなわち，1,5-COD の二つの二重結合のトランス位にあ る配位子がおたがいに異なっており，その一方が大きな $\pi$-受容 性をあつ配位子である場合には，それぞれの二重結合のまわりの 電子密度に大きな相違が生ずるため, オレフィン性水素 $\mathbf{H}_{1}$ と $\mathbf{H}_{2}$ が等価でなくなったと考えられる(図 2)。

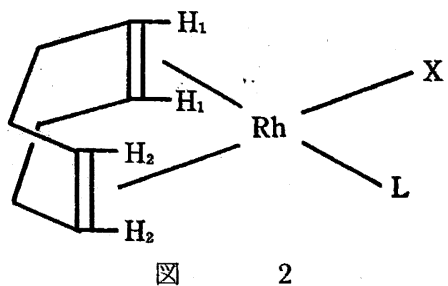

2 本の吸収の位置と配位子 $\mathrm{L}$ および $\mathrm{X}$ との関係は， $\mathrm{H}_{1}$ およ び $\mathrm{H}_{2}$ がそれぞれ二つの配位子 L および X の影響をともに受け るため複雑であり（図 1)，この関係についての詳細な議論のため 
にはよりいっそう深い検討が必要である。

\section{3 実験}

とくに記す場合のほかは，すべての操作は堂素聚囲気中で行な い，溶媒は使用直前に室素を飽和したものを用いた。NMR スペ クトルは, Varian A 60 あるいは Hitachi-Perkin Elmer R-20 を用い，TMS を内部標準として測定した。IR スペクトルは， 日本分光 DS-402G を用い測定した。ガスクロマトグラフィー分 析には，島津 GC-3AH 型を用いた。分子量は， KNAUER 製 Vapor Pressure Osmometer を用い測定した。

\section{1 アルキルロジゥム錯体の合成}

3.1.1 フェニル錯体の合成: Chatt らの方法13)により合成し た $\left[\mathrm{Rh}(1,5-\mathrm{COD}) \mathrm{Cl}_{2}[1] 0.99 \mathrm{~g}\right.$ とトリフェニルホスフィン $1.06 \mathrm{~g}$ をエーテル $5 \mathrm{~m} l$ を含むべンゼン $30 \mathrm{~m} l$ に溶解し, 室温で 15 分間かきまぜた。沓冷したのち，臭化つェニルマグネシウムの 溶液(マグネシウム $1.5 \mathrm{~g}$ ，ブロムベンゼン $7.85 \mathrm{~g}$ ，エーテル 100 $\mathrm{ml}$ から調製したものの上登液)を $20 \mathrm{~m} l$ 滴下した。10 分間かき まぜつづけたのち，純水 $20 \mathrm{ml}$ を滴下した。水層を除き，有機層 を無水硫酸ナトリウムで乾燥し，減圧下に䀼縮し，一夜冷蔵庫中 に放置すると橙色結晶が析出した。結晶はデカンテーションで分 離し, ベンゼンーヘキサン $(1: 2)$ 溶液で洗い, 減圧下に乾燥して $1.42 \mathrm{~g}$ の $\mathrm{C}_{6} \mathrm{H}_{5} \mathrm{Rh}(1,5-\mathrm{COD})\left(\mathrm{Ph}_{3} \mathrm{P}\right)[2]$ をえた〔2]はベンゼ ンから再結晶し，その性状は表 1 亿示した。

3.1 .2 ベンジル錯体の合成: 〔1 $] 0.75 \mathrm{~g}$ とトリフェニルホス フィン $0.80 \mathrm{~g}$ を塩化ベンジルマグネシウムの溶液(マグネシウム $1.1 \mathrm{~g}$, 塩化ベンジル $5.1 \mathrm{~g}$, エーテル $80 \mathrm{ml}$ から調製) $12 \mathrm{ml}$ を 用いフェニル錯体の場合と同様の処理を行なった。濃縮ベンゼン 溶液から結晶が析出しなかったので下記の方法で単離した。約 2 $\mathrm{m} l$ に濃縮したベンゼン溶液に約 $20 \mathrm{~m} l$ のヘキサンを加えた。分 離してきた油状物を除き，母液を約 $10 \mathrm{~m} l$ に裖縮し，放置すると 赤色結晶 $0.23 \mathrm{~g}$ を析出した (NMR スペクトルおよび元素分析の 結果は $\mathrm{C}_{6} \mathrm{H}_{5} \mathrm{CH}_{2} \mathrm{Rh}(1,5-\mathrm{COD})\left(\mathrm{Ph}_{3} \mathrm{P}\right)$ でないことを示したが， 詳細な検討は行なわなかった)。結晶を除いた母液に約 $10 \mathrm{~m} l$ の ヘキサンを加え放置すると赤色結晶と橙色結晶がいっしょに析出 した。この液を口過し，口液に大量のへキサンを加光放置すると 橙色結晶が析出した。デカンテーションで分別し，へキサンで洗 浄, 乾燥し，0.45 g の $\mathrm{C}_{6} \mathrm{H}_{5} \mathrm{CH}_{2} \mathrm{Rh}(1,5-\mathrm{COD})\left(\mathrm{Ph}_{3} \mathrm{P}\right)$ をえた。表 1 亿その性状を示した。

3.1.3 メチル錯体の合成：過剩のマグネシウム存在下に調製 したヨウ化メチルマグネシウムを用い，〔2〕の場合と同様に処理 し，〔2〕より赤味を帯びた橙色結晶として $\mathrm{CH}_{3} \mathrm{Rh}(1,5-\mathrm{COD})$ $\left(\mathrm{Ph}_{8} \mathrm{P}\right)$ をえた。

$3.2 〔 2 〕 と ヨ$ ウ化アルキルの反応:〔2〕0.53 g にヨウ化エチ ル $6 \mathrm{~m} l$ を加え, 室温で 30 分かきまぜた。反応液を減圧下に湛縮 した。残留物を少量のベンゼンに溶解し，多量のへキサンを加え ると褐色結晶 $0.37 \mathrm{~g}$ がえられた。この結晶の融点および IR ス ペクトルは, $\left.\mathrm{Rh}(1,5-\mathrm{COD}) \mathrm{Ph}_{3} \mathrm{P}\right) \mathrm{I}$ のそれと一致した。

〔2〕とヨウ化メチルの反応によっても同一錯体がえられた。

$3.3 \mathrm{Rh}(1,5-\mathrm{COD})\left(\mathrm{Ph}_{3} \mathbf{P}\right) \mathrm{Cl}$ と臭化エチルマグネシウムの反 応

13) J. Chatt, L. M. Venanzi, J. Chem. Soc., 1957, 4735.
$\mathrm{C}_{2} \mathrm{H}_{5} \mathrm{Rh}(1,5-\mathrm{COD})\left(\mathrm{Ph}_{8} \mathrm{P}\right)$ の合成を, 〔2〕の場合と同様の方法 で試みたが，明確な組成の錹体法えられなかった。

真化エチルマグネシウムとの反応時にガスを発生し，てのガス をガスクロマトグラフにより分析したところ，エタンとエチレン であることがわかった。

〔1〕0.75 g とトリフェニルホスフィン $3.21 \mathrm{~g}$ をべンゼン 20 $\mathrm{m} l$ に溶解し， 10 分間かきまぜたのち，エーテル $2 \mathrm{~m} l$ を加え， 水冷した。臭化エチルマグネシウムの溶液(マグネシウム $1.5 \mathrm{~g}$ ， 臭化エチル $5.5 \mathrm{~g}$, エーテル $100 \mathrm{ml}$ から調製)を $13 \mathrm{ml}$ 滴下し た。滴下中に $33 \mathrm{ml}$ のガスを発生した。ガスクロマトグラフによ る分析は，エチレン：エタン=1:0.09 で生成していることを示 した。また溶液中に黄色沈殿が生成した。口過，エーテルで洗 浄, 乾燥し, $2.70 \mathrm{~g}$ の結晶をえた。トリフェニルホスフィン 2.60 $\mathrm{g}$ を含むべンゼンから再結晶し，精製結晶 $2.20 \mathrm{~g}$ をえた(収率 63

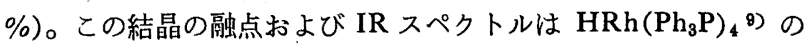
それと一致した。

\section{$3.4 \pi$-アリル錯体の合成}

〔2〕の場合と同様の方法で，自化アリルマグネシウムを用いて 反応を行ない,反応後の濃縮ベンゼン溶液にへキサンを加え，[1] に対して $32 \%$ の収率で，淡橙色結晶として $\pi-\mathrm{C}_{9} \mathrm{H}_{5} \mathrm{Rh}\left(\mathrm{Ph}_{3} \mathrm{P}\right)_{2}$ をえた。 $\mathrm{mp} 188 \sim 190^{\circ} \mathrm{C}$ (分解)。

分析值 C $70.12 \%, \mathrm{H} 5.29 \%$

$\mathrm{RhC}_{80} \mathrm{H}_{35} \mathrm{P}_{2}$ としての計算值 C $70.06 \% ， \mathrm{H} 5.28 \%$

\subsection{1,5-シクロオクタジエンロジウム錯体の合成}

この項目の実験は, 〔 1 〕と $\mathrm{AsPh}_{3}, \mathrm{P}(\mathrm{OPh})_{3}$, 一酸化炭素との 反応以外はすべて空気中で行なった。

$[\mathrm{Rh}(1,5-\mathrm{COD}) \mathrm{X}]_{2}(\mathrm{X}=\mathrm{Br}, \mathrm{I})$ の合成は，Chatt ら $\left.{ }^{13}\right)$ の方法 にしたがい[1]から合成した。

\subsubsection{Rh(1,5-COD $) \mathbf{L X}$ 型錯体の合成}

(a): Chatt らの $\mathrm{Rh}(1,5-\mathrm{COD})\left(\mathrm{Ph}_{8} \mathrm{P}\right) \mathrm{Gl}$ の合成法 $\left.{ }^{18}\right)$ にした がい，一般的には下記のようにして行なった。

1.02〜1.05 倍当量の配位子 $\mathrm{L}$ を含む二塩化メチレン溶液を $[\mathrm{Rh}(1,5-\mathrm{COD}) \mathrm{X}]_{2}$ に加光，10〜15 分間室温でかきまぜた。光 られた溶液を減圧下に濃縮し，へキサンを加えると結晶が析出し た。デカンテーションで分別し, 結晶はへキサンで洗浄, 乾燥し た。二瑥化メチレンーヘキサンあるいはベンゼンーヘキサン采で 2 〜 回再結晶した。

(b): $\mathrm{Rh}(1,5-\mathrm{COD})\left(\mathrm{Ph}_{3} \mathrm{P}\right)(\mathrm{NCO})$ と $\mathrm{Rh}(1,5-\mathrm{COD})\left(\mathrm{Ph}_{3} \mathrm{P}\right)$ (NCS)の合成は下記のようにした。

$\mathrm{Rh}(1,5-\mathrm{COD})\left(\mathrm{Ph}_{3} \mathrm{P}\right) \mathrm{Cl} 0.80 \mathrm{~g}$ と細粉したシアン酸カリウム $0.18 \mathrm{~g}$ にアセトン $150 \mathrm{~m} l$ を加え 3.5 時間室温でかきまぜた。口 過し, 口夜を裖縮し, 析出する黄色結晶を口過した。結晶は二塩 化メチレンーヘキサン系で 2 回再結晶し, 黄色結晶として $\mathrm{Rh}(1$, 5-COD) $\left(\mathrm{Ph}_{3} \mathrm{P}\right)(\mathrm{NCO}) 0.45 \mathrm{~g}$ をえた。

$\mathrm{Rh}(1,5-\mathrm{COD})\left(\mathrm{Ph}_{3} \mathrm{P}\right)(\mathrm{NCS})$ の合成は，チオシアン酸カリウム を用い，同様にして行なった。この錯体は溶液にすると不安定で あり, 室温では徐々に, 加熱すると急速に黄色から赤褐色に変化 した。

(c):〔1]と $\mathrm{Ph}_{3} \mathrm{Sb}$ との反応では, 未反応の 1 1 と $\mathrm{Rh}(1,5-$ $\mathrm{COD})\left(\mathrm{Ph}_{8} \mathrm{Sb}\right)_{2} \mathrm{Cl}$ がえられ, 後者の収率は[ 1 〕に対して 2 倍当 量の $\mathrm{Ph}_{3} \mathrm{Sb}$ を用いると向上した。

(d):〔1〕と $\mathrm{P}(\mathrm{OPh})_{3}$, 一酸化炭素との反応からは $\mathrm{Rh}(1,5-$ 


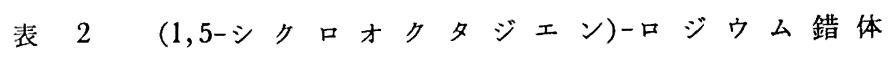

\begin{tabular}{|c|c|c|c|c|c|c|c|}
\hline & 収率 & & 号点 (分解) ${ }^{a}$ ) & 元 & 分 析 & $(\%)^{b)}$ & \\
\hline & $(\%)$ & हैत्य & $\left({ }^{\circ} \mathrm{G}\right)$ & C & $\mathrm{H}$ & $\mathrm{Cl}$ & \\
\hline $\begin{array}{c}\mathrm{Rh}(1,5-\mathrm{COD})\left(\mathrm{Ph}_{3} \mathrm{P}\right) \mathrm{X} \\
\mathrm{X}=\mathrm{Cl}\end{array}$ & & & & & & & $\begin{array}{l}513^{e)} \\
(509)\end{array}$ \\
\hline $\mathrm{Br}$ & 54 & 褐色 & $133 \sim 135$ & $\begin{array}{c}56.77 \\
(56.44)\end{array}$ & $\begin{array}{c}4.95 \\
(4.92)\end{array}$ & & \\
\hline I & 62 & 褐色 & $.134 \sim 136$ & $\begin{array}{c}51.70 \\
(52.02)\end{array}$ & $\begin{array}{c}4.56 \\
(4.53)\end{array}$ & & \\
\hline $\mathrm{NCO}$ & 56 & 黄色 & $141 \sim 143$ & $\begin{array}{c}62.67 \\
(62.92)\end{array}$ & $\begin{array}{c}5.27 \\
(5.28)\end{array}$ & & \\
\hline NGS & 40 & 黄色 & $135 \sim 137$ & $\begin{array}{c}60.54 \\
(61.02)\end{array}$ & $\begin{array}{c}5.08 \\
(5.12)\end{array}$ & & \\
\hline \multicolumn{8}{|l|}{$\operatorname{Rh}(1,5-\mathrm{COD}) \mathrm{LGl}$} \\
\hline $\mathrm{L}=\mathrm{Et}_{3} \mathrm{P}$ & - & 黄色 & $1 \cdot 17 \sim 118$ & $\begin{array}{c}45.84 \\
(46.10)\end{array}$ & $\begin{array}{c}7.54 \\
(7.46)\end{array}$ & & $\begin{array}{c}\left.364^{e}\right) \\
(365)\end{array}$ \\
\hline $\mathrm{Ph}_{2} \mathrm{MeP}$ & 38 & 黄色 & 126 & $\begin{array}{c}56.51 \\
(56.46)\end{array}$ & $\begin{array}{c}5.72 \\
(5.64)\end{array}$ & & \\
\hline$\left(p-\mathrm{CH}_{3} \mathrm{C}_{6} \mathrm{H}_{4}\right)_{3} \mathrm{P}$ & 62 & 黄色 & $134 \sim 135$ & $\begin{array}{c}63.43 \\
(63.22)\end{array}$ & $\begin{array}{l}6.46 \\
(6.02)\end{array}$ & $\begin{array}{c}6.79 \\
(6.44)\end{array}$ & \\
\hline$\left(p-\mathrm{ClC}_{6} \mathrm{H}_{4}\right)_{3} \mathrm{P}$ & 42 & 黄色 & $139 \sim 140$ & $\begin{array}{c}50.13 \\
(51.01)\end{array}$ & $\begin{array}{c}3.98 \\
(3.95)\end{array}$ & $\begin{array}{c}23.62 \\
(23.17)\end{array}$ & \\
\hline $\mathrm{Ph}_{3} \mathrm{As}$ & 65 & 橙色 & $144 \sim 145$ & $\begin{array}{c}55.95 \\
(56.49)\end{array}$ & $\begin{array}{c}4.87 \\
(4.92)\end{array}$ & $\begin{array}{c}6.25 \\
(6.41)\end{array}$ & \\
\hline $\mathrm{NH}_{3}$ & 46 & 黄色 & $249 \sim 250$ & $\begin{array}{c}36.65 \\
(36.45)\end{array}$ & $\begin{array}{c}5.73 \\
(5.74)\end{array}$ & $\begin{array}{c}13.27 \\
(13.45)\end{array}$ & \\
\hline $\mathrm{C}_{5} \mathrm{H}_{5} \mathrm{~N}$ & 78 & 黄色 & $228 \sim 229 c)$ & $\begin{array}{c}47.62 \\
(47.95)\end{array}$ & $\begin{array}{c}5.23 \\
(5.26)\end{array}$ & & $\begin{array}{l}\left.333^{f}\right) \\
(326)\end{array}$ \\
\hline $\mathrm{Rh}(1,5-\mathrm{COD})\left(p-\mathrm{NH}_{2} \mathrm{C}_{6} \mathrm{H}_{4}-\mathrm{CH}_{3}\right) \mathrm{Br}$ & 40 & 黄色 & $213 \sim 214$ & $\begin{array}{c}45.71 \\
(45.25)\end{array}$ & $\begin{array}{c}5.44 \\
(5.32)\end{array}$ & & \\
\hline $\mathrm{Rh}(1,5-\mathrm{GOD})\left(\mathrm{C}_{5} \mathrm{H}_{5} \mathrm{~N}\right) \mathrm{I}$ & 53 & 黄色 & $\left.195 \sim 210^{d}\right)$ & $\begin{array}{l}37.47 \\
(37.43)\end{array}$ & $\begin{array}{c}4.16 \\
(4.11)\end{array}$ & & \\
\hline $\mathrm{Rh}(1,5-\mathrm{COD})\left(\mathrm{Ph}_{3} \mathrm{Sb}\right)_{2} \mathrm{Cl}$ & 42 & 赤色 & $105 \sim 109$ & $\begin{array}{c}56.04 \\
(55.47)\end{array}$ & $\begin{array}{c}4.58 \\
(4.44)\end{array}$ & $\begin{array}{c}3.94 \\
(3.72)\end{array}$ & \\
\hline
\end{tabular}

注 $\quad a$ ) 柳本 MP-2S 型融点測定装置を用い，空気中で測定した。未補正. $\quad b$ ) カッコ内は計算值.

c） $110 \sim 130^{\circ} \mathrm{C}$ で融解することなく变色した. d ) $85 \sim 100^{\circ} \mathrm{C}$ で融解することなく変色した.

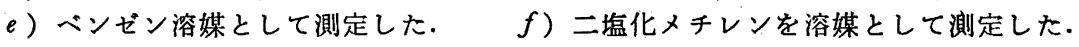

GOD)LGl 型の錯体はえられなかった。一酸化炭素との反応の場 合には，反応液を減圧下に濃縮すると[1]が回収され，一酸化炭 素雾囲気中で濃縮すると $\left[\mathrm{Rh}(\mathrm{CO})_{2} \mathrm{Gl}\right]_{2}$ がえられた。

合成した錯体のうち新しい錯体の収率，色調，融点，元素分 析，分子量測定の結果を表 2 に示した。

また NMR の結果を図 2 に示した。NMR スペクトルは $\mathrm{C}_{6} \mathrm{D}_{6}$ または $\mathrm{CDCl}_{3}$ を溶媒とし，10 w/v\% の濃度で $34.5^{\circ} \mathrm{C}$ で則定 した。ただし $\mathrm{Rh}(1,5-\mathrm{GOD})\left(\mathrm{NH}_{3}\right) \mathrm{Gl}$ および $p$-トルイジン錯体 は溶解度が小さいためこの濃度以下である。また Rh(1,5-COD) $\left(\mathrm{Ph}_{3} \mathrm{P}\right) \mathrm{Cl}$ の吸収の位置は濃度 4〜 $16 \mathrm{w} / \mathrm{v} \%$ の間で变化しなかっ た。吸収の位置は面積中心值とし，その再現性は $\pm 0.02 \mathrm{ppm}$ で あった。

3.5.2 $\mathbf{R h}(\mathbf{1}, \mathbf{5}-\mathbf{G O D})\left(\mathbf{P h} \mathbf{h}_{3} \mathbf{P}\right) \mathbf{G l}$ とシアン化ナトリウムの反
応: $\mathrm{Rh}(1,5-\mathrm{COD})\left(\mathrm{Ph}_{3} \mathrm{P}\right) \mathrm{Gl} 0.52 \mathrm{~g}$ をベンゼン $10 \mathrm{ml}$ に溶解し， シアン化ナトリウム $0.53 \mathrm{~g}$ を含む水溶液 $10 \mathrm{ml}$ と室温で 10 分 間ふりまぜた。反応液は口過し，二層を分離し，水層はベンゼン で抽出した。ベンゼン溶液を合一し，ガスクロマトグラフで分析

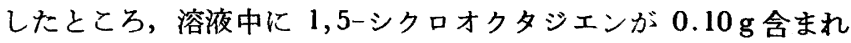
ていることがわかった。なお 1,3-シクロオクタジェンの吸収は 認められなかった。

NMR スペクトルの測定は大阪大学理学部および大阪大学産業 科学研究所 NMR 測定室の諸氏に, 元素分析は同研究所藤野卓三 氏，芝野敏樹氏に，分子量測定は同研究所宍戸経世氏にお世話に なった。以上の各位に厚く感謝する。

（1967 年 4 月，日本化学会第 20 年会：1967 年 10 月，有楼金 属化合物討論会 (大阪) 発表) 